\title{
TEKNIK MEMBACA BUKU DENGAN MEMBUKA-BUKA BUKU
}

\author{
Prana Dwija Iswara \\ PGSD Universitas Pendidikan Indonesia Kampus Sumedang \\ Jl. Mayor Abdurachman No. 211 Sumedang \\ Email: prana_badrun@yahoo.com
}

\begin{abstract}
Openning book is one of human daily activities when they read books. When someone openning book, she or he has not done something that does not have any purpose. There are many benefits in opennig book activities, one of them is retrieving comprehension as much as possible. Openning book means repeatedly openning the pages, reading important portion of the page and skipping less important portion of the page. Openning books activity can be being done in a relatively short time (e.g. five minutes or half an hour) and will have been completed once at a time. Openning book reading technique can be used even by the students in elementary school. Therefore, openning book reading technique is claimed to be the one of important reading technique for reading study. Keywords: repeatedly openning the page, openning book, reading, elementary school.
\end{abstract}

ABSTRAK

Membuka-buka buku merupakan salah satu kegiatan yang dilakukan saat membaca buku. Seseorang melakukan kegiatan membuka-buka buku bukan tanpa tujuan. Membuka-buka buku pun mempunyai manfaat, di antaranya mengambil pemahaman dari buku yang dibuka-buka itu. Membuka-buka buku berarti membaca bagian yang penting dari buku itu dan melewati bagian yang kurang penting. Kegiatan membuka-buka buku dapat dilakukan dalam waktu yang singkat (misalnya lima menit sampai setengah jam) dan bisa selesai dalam satu waktu. Teknik membuka-buka buku dapat digunakan bahkan untuk jenjang sekolah dasar. Membuka-buka buku diklaim sebagai salah satu teknik membaca buku yang penting dalam belajar membaca.

Kata kunci: membuka-buka buku, membaca, sekolah dasar.

PENDAHULUAN Membuka-buka buku merupakan salah satu kegiatan yang dilakukan saat membaca buku. Di dalam teori membaca pada umumnya seorang pembaca melakukan kegiatan membaca dengan membaca dari awal teks halaman sampai akhir teks halaman. Seorang yang membaca artikel akan membaca artikel itu dari awal teks artikel sampai akhir teks artikel.

Namun mungkin saja seorang pembaca artikel itu tengah memengang jurnal (kumpulan artikel). Pembaca itu lalu melihat-lihat artikel yang menarik baginya. Mungkin pembaca itu akan melihat judul-judul artikel. Mungkin pula pembaca itu akan membuka-buka jurnal itu ketika judul artikel jurnal itu banyak yang menarik perhatiannya. Ketika ia memutuskan bahwa banyak judul artikel yang menarik, ia akan membuka-buka jurnal itu untuk melihat- lihat artikel yang judulnya menarik itu. Ia akan membuktikan bahwa artikel itu benar-benar menarik atau tidak.

Mungkin juga seseorang akan membolakbalik halaman suatu artikel untuk membuktikan bahwa artikel itu bagus atau buruk. Bisa saja ia melewati bagian yang kurang penting dan terfokus pada bagian yang penting. Pada akhirnya ia akan mempunyai kesimpulan dari kegiatan membacanya itu. Mungkin ia beroleh pengetahuan yang berharga dari kegiatan membacanya itu.

Dengan begitu, seorang pembaca tidak selamanya harus membaca dari awal teks halaman sampai akhir teks halaman. Ia akan membaca subjudul kemudian memutuskan untuk membaca isi teks dari subjudul itu. Ia juga bisa memutuskan untuk tidak membaca isi teks dari subjudul itu karena ia merasa bahwa teks itu 
tidak penting baginya.

\section{PERTANYAAN: BERMANFAATKAH MEMBUKA-BUKA BUKU?}

Seseorang melakukan kegiatan membukabuka buku bukan tanpa tujuan. Membuka-buka buku pun mempunyai manfaat, di antaranya mengambil pemahaman dari buku yang dibukabuka itu. Apa manfaatnya bila seseorang membuka-buka buku tetapi ia tidak beroleh manfaat dari kegiatan membuka-buka buku itu? Seseorang harus memperoleh manfaat dari kegiatan membuka-buka buku.

Membuka-buka buku dilakukan dengan membaca teks yang ada di dalamnya. Sekalipun teks yang dibaca tidak selamanya harus dari awal teks halaman sampai teks akhir halaman. Ia cukup perlu melihat apakah halaman itu bermanfaat baginya untuk dibaca. Kemudian ia memutuskan untuk membaca bagian yang penting dari teks itu. Ketika ia merasa bahwa halaman itu tidak penting, maka ia dapat berlih ke halaman lain. Ketika ia merasa bahwa halaman itu sudah dipahami, maka ia dapat berlih ke halaman lain.

Kegiatan membuka-buka buku bahkan merupakan kegiatan yang penting saat memilih buku di perpustakaan atau memilih buku yang hendak dibeli di toko buku. Apakah seseorang akan membeli buku hanya dengan melihat judul bukunya dan melihat gambar atau tulisan di jilid depannya saja? Mungkin saja demikian, tetapi, calon pembaca akan mencari informasi sebanyak mungkin dari buku yang hendak dibaca atau dibelinya. Kegiatan ini mirip dengan kegiatan survey dalam teknik SQ3R (Soedarso, 1988; Nurhadi, 2004; Hardjasudjana dan Mulyati, 1996; Wikipedia, 2013f; Tampubolon, 1990; Tarigan, 1983).

Dengan begitu, kegiatan membuka-buka buku sebenarnya kegiatan yang alami bagi pembaca buku. Menariknya adalah munculnya pertanyaan: dapatkah membuka-buka buku dilakukan hingga akhir buku? Berapa lama waktu yang diperlukan untuk membuka-buka buku?

\section{MEMBUKA-BUKA BUKU DARI AWAL HINGGA AKHIR BUKU}

Bila seseorang berpikir untuk membaca buku dari awal hingga akhir buku, mengapa ia tidak berpikir untuk membuka-buka buku itu dari awal hingga akhir. Apakah seorang yang baru mendapat hadiah sebuah buku akan membacanya dari awal sampai akhir? Adakah kemungkinan lain, ia membuka-buka buku itu seperti seorang anak kecil yang baru mendapatkan buku bergambar lalu dengan perasaan senang ia membuka-buka buku itu dari awal hingga akhir?

Pembaca akan memutuskan apakah ia akan membaca dari teks awal halaman sampai akhir teks, ataukah ia akan membuka-buka buku itu. Pembaca yang rajin atau mempunyai motivasi yang tinggi akan membaca buku. Pembaca yang malas akan enggan membaca buku sekalipun acap kali guru melatih siswa untuk membaca buku yang tebal. Guru acap kali membiasakan siswa membaca buku yang tebal. Guru acap kali memerintahkan siswa membaca buku yang tebal untuk membiasakan siswa membaca buku.

Salah satu keluhan pembelajar saat ini ialah mereka kurang mampu membaca buku. Melihat buku yang tebal, dengan tema yang asing, dan mungkin berbahasa asing akan membuat minat baca mereka menurun.

Pembaca yang malas begitu mendapat buku tebal dan padat dengan istilah asing akan enggan membaca buku itu. Tetapi pembaca dengan motivasi yang tinggi akan membuka-buka buku bahkan buku yang kurang dipahaminya. Acap kali guru memberi tugas untuk membaca buku yang asing bagi siswa. Guru menugasi siswa membaca buku linguistik yang asing bagi siswa. Guru menugasi siswa membaca novel jaman dulu (jadul) yang tidak ramai dibicarakan pembaca. Guru menugasi siswa membaca teknik forehand, backhand, slice backhand, two handed backhand, serve, volley, drop shot, lob, grip, string, string tension, double strung, spaghetti string dalam permainan tenis. Padahal permainan tenis adalah permainan yang asing bagi siswa. Mungkin juga guru menugasi siswa membaca teknik sepak bola: dribling, passing, shooting; padahal siswa lebih suka dilatih bermain sepak bola daripada membaca tekniknya dari buku.

Teknik membuka-buka buku merupakan salah satu solusi bagi pembaca yang "malas" membaca. Sayangnya banyak masyarakat atau pembelajar negeri ini yang dikatakan malas membaca. Banyak yang mengatakan bahwa 
masyarakat negeri ini rendah daya bacanya. Teknik membaca buku dengan membuka-buka buku akan menjadi solusi bagi para pembaca demikian. Lebih jauh, teknik membuka-buka buku merupakan solusi bagi seseorang yang tidak mempunyai waktu khusus untuk membaca seperti di perjalanan, waktu menunggu, atau membaca bagi ibu rumah tangga yang tidak diharuskan membaca. Selain itu membuka-buka buku juga merupakan solusi bagi "pembaca profesional" yang berkehendak menggunakannya.

Dengan begitu, teknik membuka-buka buku dapat diajarkan di sekolah, baik di sekolah dasar, sekolah menengah maupun di perguruan tinggi (Kementerian Pendidikan dan Kebudayaan Republik Indonesia, 2013). Bahkan bila di perguruan tinggi banyak mahasiswa yang enggan membaca, teknik membuka-buka buku ini akan menolong mereka untuk mengenal isi buku. Sebaliknya, bila mahasiswa di perguruan tinggi mempunyai motivasi yang tinggi untuk membaca dan mereka terbiasa membaca buku, teknik membuka-buka buku ini bisa menjadi teknik yang membantu mereka memahami isi buku dengan cepat.

\section{MEMBACA BAGIAN PENTING DAN MELEWATI BAGIAN YANG KURANG PENTING}

Membuka-buka buku berarti membaca bagian yang penting dari buku itu dan melewati bagian yang kurang penting. Membuka-buka buku dapat dilakukan dengan cepat. Namun ketika pembaca membuka suatu halaman, ia harus membaca teks yang ada di dalamnya. Ia dapat membaca apapun yang ada pada halaman itu: teks, judul, subjudul, gambar, bagan, tabel dan lain-lain. Jadi ketika tangan membuka-buka buku, mata mesti memperhatikan hal-hal yang ada pada dua halaman bacaan. Teknik ini mirip dengan teknik baca-pilih dan teknik baca-lompat yang diungkap Mulyati (2009: 156).

Ketika membaca suatu halaman, ada kalanya pembaca akan memutuskan bahwa halaman itu penting. Mungkin saja pada tahap ini lalu pembaca menandai bacaan atau membuat catatan di marjin halaman. Sebaliknya bila pembaca memutuskan bahwa tidak ada yang menarik di halaman itu, ia akan menggerakkan tangannya membuka halaman berikutnya.
Menandai bacaan dapat dilakukan dengan pensil. Menandai bacaan tidak direkomendasikan menggunakan bolpen atau spidol warna yang tidak bisa dihapus. Menandai bacaan juga dilakukan dengan menandai kata dan bukan menandai baris. Jadi tidak seluruh baris ditandai melainkan kata kunci penting saja di sisi kiri, tengah atau kanan halaman.

\section{WAKTU YANG DIPERLUKAN UNTUK MEMBUKA-BUKA BUKU}

Kegiatan membuka-buka buku dapat dilakukan dalam waktu yang singkat (misalnya lima menit sampai setengah jam) dan bisa selesai dalam satu waktu. Buku yang tebalnya 200 halaman bisa saja dibuka-buka selama lima belas menit. Namun ada kalanya pembaca baru membuka seperempat, sepertiga atau setengahnya; ia sudah menutup bukunya lantaran mendapatkan pencerahan.

Membaca buku memang suatu kenikmatan sehingga ketika seseorang mendapat pencerahan, ia akan berhenti dan mencerna pencerahan itu dengan baik. Ia tidak akan melanjutkan membaca yang akhirnya melupakan pencerahan yang ia dapatkan.

Seberapa kuatkah seseorang membaca buku? Mungkin ada orang yang kuat membaca buku hanya dalam waktu setengah jam. Tetapi mungkin ada orang yang lebih dari itu. Bila seseorang menemukan buku yang ia sukai, ia akan kuat membaca buku sampai berjam-jam atau seharian. Dalam pengalaman, pernah seseorang membaca buku sebanyak kurang lebih 150 halaman dalam waktu kurang dari sehari. Padahal ia tidak hanya membuka-buka buku, ia membaca secara intensif buku itu dari awal sampai akhir!

Mungkin saja seseorang mempunyai waktu luang selama 15 menit di sekolah, di area istirahat, di ruang tunggu, di antrean atau di rumah. Ia dapat menghabiskan waktunya untuk membuka-buka buku. Mungkin seseorang hanya kuat membaca buku selama 15 menit saja, maka ia melakukan membuka-buka buku selama 15 menit, dan ia merasa kelelahan. Ia dapat berhenti sampai rasa lelahnya hilang. Bila membaca membuatnya jenuh, maka ia dapat menghentikan aktivitas membacanya. Ia dapat melakukan penyegaran dengan berbicara dengan orang lain, pergi beibadah, ber-i'tikaf di tempat 
ibadah, mengerjakan aktivitas lain (mengetik, atau berinternet), atau menonton televisi. Setelah rasa jenuhnya hilang, motivasinya dan rasa ingin tahunya tumbuh, ia dapat kembali mengambil bacaannya dan kembali membuka-buka bukunya

Tindakan atau kegiatan membuka-buka buku dapat dilakukan berkali-kali dalam sehari. Pernah terjadi seorang siswa disuruh oleh guru untuk mempelajari suatu buku. Ia membukabuka buku dan beralih ke aktivitas lain, membuka-buka buku dan beralih ke aktivitas lain. Hal itu dilakukan agar ia memenuhi permintaan gurunya. Akhirnya ia menguasai buku itu untuk disajikan di depan guru dan teman-temannya.

\section{TEKNIK MEMBACA DENGAN MEDIA LAIN}

Membaca dapat dilakukan di beragam tempat. Seseorang membaca ketika ia membuka internet (Wikipedia, 2008a) , di atas bus, teks terjemahan film di televisi, berita berjalan (running text). Teks di internet pun dapat dibaca dengan cepat (Wikipedia, 2013e). Demikian pula seseorang akan membaca dengan cepat ketika ia berada di atas bus dan membaca spanduk di pinggir jalan, ia pun membaca cepat ketika membaca teks terjemahan film televisi, atau membaca berita berjalan. Dengan begitu membaca tidak selamanya dilakukan dengan memperhatikan setiap huruf atau setiap kata.

Mungkin juga seseorang mengabaikan teks yang tidak hendak ia baca. Dengan begitu, seseorang mempunyai tujuan ketika membaca. Ia membaca teks yang ia rasa penting, dan mengabaikan teks yang sudah ia pahami. Dengan mengabaikan teks yang sudah dipahami, ia bisa lebih cepat membaca dan melewati bagian yang sudah dipahaminya itu.

\section{EVALUASI MEMBACA}

Evaluasi membaca dapat dilakukan dengan meminta pembaca menuliskan sejumlah hal yang berkaitan dengan bacaan. Pembaca dievaluasi dengan menuliskan empat atau lima hal berkaitan dengan bacaan. Evaluasi seperti ini adalah soal yang terbuka. Seorang pembaca bisa memberi perhatian pada satu bagian bacaan yang berbeda dengan orang lain. Seorang pembaca bisa mengingat sesuatu yang berbeda dengan orang lain. Seorang pembaca mungkin mengingat nama, peristiwa atau istilah. Pembaca lain mungkin mengingat waktu, tempat dan hal lainnya. Evaluasi membaca dapat membuat laporan bacaan dengan menuliskan kembali isi bacaan.

Evaluasi juga dapat dilakukan dengan meminta pembaca menjawab soal berdasarkan bacaan. Di sini pembaca harus mengingat bacaan sesuai keinginan pembuat soal. Bisa saja perhatian pembuat soal berbeda dengan perhatian pembaca. Pembuat soal membuat soal yang sulit terjawab oleh pembaca. Sebaliknya pembaca mengingat hal-hal yang menyenangkan dan mudah diingat.

Evaluasi membaca dapat dilakukan dengan evaluasi membaca pada umumnya. Ada kalanya evaluasi dilakukan tanpa memperkenankan pembaca melihat kembali bacaannya. Namun evaluasi yang cenderung berupa latihan memungkinkan seseorang untuk membaca kembali bacaannya. Lebih jauh, alih-alih mengingat jawaban, pembaca akan membaca pertanyaan sebelum mencari jawabannya di dalam bacaan. Pada sisi ini, evaluasi tanpa melihat kembali jawaban akan melatih pembaca untuk mengingat bacaan. Penilaian dalam membaca dapat menggunakan rujukan evaluasi yang lazim misalnya Arikunto (1999), Akhadiah (1988), dan Hidayat; Sapani; Abidin, (1994). Evaluasi juga dapat pula menggunakan pengukuran keterbacaan (DuBay, 2004; Wikipedia, 2008b; Wikipedia, 2013a; Wikipedia, 2013d).

Membaca dengan teknik apa pun akan mengedapankan pemahaman yang maksimal. Memang bisa saja teknik membaca cepat mereduksi tingkat pemahaman. Namun, setidaknya dalam studi kasus yang pernah dilakukan, ternyata membaca dalam waktu yang lama dan membaca dalam waktu yang relatif singkat tidak memberi perbedaan. Harus diperhatikan bahwa pemahaman maksimal (100\%) semestinya tetap diupayakan.

\section{SIMPULAN}

Membuka-buka buku diklaim sebagai salah satu teknik membaca buku yang penting dalam belajar membaca. Teknik ini memang dikembangkan dari teknik-teknik yang ada. Mulyati (2009: 156) mengungkapkan teknik bacapilih dan teknik baca-lompat yang menjadi sebagian dasar teknik baru ini. Teori lain seperti 
yang diungkap Hardjasudjana dan Damaianti (2003) pun memberikan dasar bagi pengembangan teknik membaca buku ini. Teknik membaca buku ini diklaim sebagai temuan baru dalam khazanah teknik pembelajaran membaca lanjut. Teknik membaca ini dapat diterapkan di semua jenjang sekolah, mulai dari sekolah dasar, sekolah menangah dan perguruan tinggi. Hanya saja, buku bacaan yang diberikan kepada siswa sekolah dasar semestinya tidak terlalu tebal, hurufnya besar dan memuat gambar-gambar yang menarik pembaca. Teknik membuka-buka buku dapat digunakan untuk membantu pembaca menguasai bacaan. Teknik ini merupakan teknik yang cepat untuk mengetahui gambaran isi buku. Teknik ini pun akan meningkatkan motivasi membaca karena pembaca tidak harus membaca dari kata pertama di suatu halaman sampai akhir kata pada halaman itu. Teknik ini bisa meningkatkan minat baca para siswa. Teknik ini pun dapat digunakan pada berbagai disiplin ilmu, eksakta atau noneksakta. Lebih lanjut teknik membaca buku ini dapat dikombinasikan dengan waktu membaca (Razak, 2004).

Teknik ini merupakan teknik yang cepat untuk mengetahui gambaran isi buku. Bila melihat teknik SQ3R, maka teknik membukabuka buku merupakan teknik yang mengoptimalkan langkah survey. Langkah survey dilakukan berulang-ulang sambil membaca hal-hal yang dirasa penting. Langkah survey dilakukan pada waktu yang berbedabeda. Teknik membuka-buka buku tidak memasukkan langkah question, read, recite, dan review.

\section{REFERENSI}

Abdul Razak (2004) Formulla 247 Plus: Mendidik Anak Menjadi Pembaca yang Sukses. Jakarta: PT Elex Media Komputindo.

Akhadiah M.K., S. (1988) Evaluasi dalam Pengajaran Bahasa. Jakarta: Proyek Pengembangan Lembaga Pendidikan Tenaga Kependidikan - Departemen Pendidikan dan Kebudayaan.

Arikunto, S. (1999) Dasar-dasar Evaluasi Pendidikan. Edisi Revisi. Jakarta: PT Bumi Aksara.

DuBay, W.H. (2004) The Principles of Readability [Online]. Tersedia: http://www.impact- information.com/impactinfo/readability02.pdf [19 Mei 2013].

Hardjasudjana, A.S. (dkk) (tanpa tahun) Materi Pokok Membaca. Jakarta: Penerbit Karunika Jakarta-Universitas Terbuka.

Hardjasudjana, A.S. dan Mulyati, Y. (1996) Membaca 2. Jakarta: Departemen Pendidikan dan Kebudayaan.

Hardjasudjana, A.S., dan Damaianti, V.S. (2003) Membaca dalam Teori dan Praktik. Bandung: Mutiara.

Hidayat, K., Sapani, S., dan Abidin, Z. (1994) Evaluasi Pendidikan dan Penerapannya dalam Pengajaran Bahasa Indonesia. Bandung: Alfabeta.

Kementerian Pendidikan dan Kebudayaan Republik Indonesia (2013) Salinan Lampiran Peraturan Menteri Pendidikan dan Kebudayaan Nomor 67 Tahun 2013 Tentang Kerangka Dasar dan Struktur Kurikulum Sekolah Dasar/Madrasah Ibtidaiyah. Jakarta.

Mulyati, Y. (2009) "Kecepatan Efektif Membaca: Apa, Mengapa, dan Bagaimana?" Bahasa dan Sastra Indonesia di Tengah Arus Global. Bandung: Jurusan Pendidikan Bahasa dan Sastra Indonesia.

Nurhadi (2004) Membaca Cepat dan Efektif (Teori dan Latihan). Bandung: Sinar Baru Algensindo.

Soedarso (1988) Speed Reading: Sistem Membaca Cepat dan Efektif. Jakarta: Gramedia Pustaka Utama.

Tampubolon, D.P. (1990) Kemampuan Membaca: Teknik Membaca Efetif dan Efisien. Bandung: Angkasa.

Tarigan, H.G. (1983) Membaca sebagai Suatu Keterampilan Berbahasa. Bandung: Angkasa.

Wikipedia (2008a) Pembelajaran Elektronik [Online]. Tersedia: http: \\id.wikipedia.org \wiki \E-learning.htm [27 Desember 2008].

Wikipedia (2008b) Raygor Readability Estimate [Online]. Tersedia: http://en.wikipedia.org/wiki/Raygor_Readabil ity_Estimate [19 Mei 2013].

Wikipedia (2013a) Flesch-Kincaid readability test [Online]. Tersedia: http://en.wikipedia.org/wiki/Flesch\%E2\%80\% 93Kincaid_readability_test [19 Mei 2013].

Wikipedia (2013d) Readability [Online]. Tersedia: http://en.wikipedia.org/wiki/Readability [19 
Mei 2013].

Wikipedia (2013e) Speed Reading [Online] Tersedia:

http://en.wikipedia.org/wiki/Speed_reading

[23 Mei 2013]
Wikipedia (2013f) SQ3R [Online]. Tersedia: http://en.wikipedia.org/wiki/SQ3R [19 Mei 2013]. 